\title{
ANALYSIS AND CONNECTION DESIGNS OF PRECAST LOAD BEARING WALL
}

\author{
A.Surekha ${ }^{1}$, J.D.Chaitanya Kumar ${ }^{2}$, E.Arunakanthi ${ }^{3}$ \\ ${ }^{1} P G$ Scholar, JNTU Ananthapuram \\ ${ }^{2}$ Assistant Professor, NRI Institute of Technology Pothavarappadu, Krishna District \\ ${ }^{3}$ Assistant Professor, JNTU Ananthapuram
}

\begin{abstract}
Lateral load on a multistory building is most critical one to consider for the design. In order to observe the seismic effect and wind effect on multi-story building, a study on precast load bearing wall of $G+11$ has been carried out. Four different seismic zones and all wind zones are considered for analysis using ETABS. The structural response due to lateral loads with load combination is extracted. Effect of lateral load on out-of-plane moments, axial forces, shear force, base shear, maximum storey drift and tensile forces on shear wall are plotted. Finally the effect of seismic zone and wind zone is tabulated.
\end{abstract}

Keywords: shear wall, ETABS, seismic and wind, precast, connection

\section{INTRODUCTION}

Seismic loads are occasional forces that may occur during the life time of a building. Buildings should be able to withstand seismic loads due to minor earthquake without any structural damage and major earthquake without total collapse. Therefore, it is important to know the behavior of multi storied buildings under lateral load. In the present study, an attempt is made to study the difference in structural behavior of 3-dimensional $\mathrm{G}+11$ storeys. The detailed study is carried out for zone - II to zone-V seismic zones of India as per IS 1893 (part1):2002, and wind speeds ranging from $39 \mathrm{~m} / \mathrm{sec}$ to $50 \mathrm{~m} / \mathrm{sec}$. The load bearing precast wall and slab structure is modeled in ETABS. Shear wall systems are one of the most commonly used lateral load resisting in high rise building. Shear wall has large in plane stiffness and strength which can be used to simultaneously resist large horizontal loads and support gravity loads.

Devi et, al. (2009) worked on the top storey deflection for a multi-storey building with and without the shear wall. Venkatesh and Bai (2011) has carried out an investigation study on effect of internal and external shear wall on performance of building frame subjected to lateral load. Balkaya and Kalkan (2004), has carried out threedimensional effect on openings of laterally loaded pierced shear walls. Janaraj et, al. (2011) has carried out wider reinforced masonry shear walls subjected to cyclic lateral loading.

Kevadkar and Kodag (2013) has carried out lateral analysis of R.C.C building and concluded that the lateral displacement of the building is reduced by $40 \%$ to $60 \%$ by the use of shear wall. Carpinteri et, al. (2012) has carried out lateral load effects on tall structures of different heights. Agrawal and Charkha (2012) has carried out the effect of change in shear wall location on storey drift of multistory building subjected to lateral loads, and concluded that with the increase in eccentricity, the building shows non-uniform movement of right and left edges of roof due to torsion and induces excessive moment and forces in member.

Rahman et. al, (2012) has carried out analysis of drift due to wind and earthquake loads on tall structures by programming language $\mathrm{C}$, and have concluded that every tall structure should include the drift due to earthquake load as well as wind load. Inter storey drift is greatest in moment frame and least in dual systems while that of that of the shear wall system is slightly higher than that of the dual system Arum and Akinkunmi (2011).

The use of shear wall is a good way to provide more level of ductility and getting more stable behavior and appear to be a novel approach to reduce of soft storey in seismic response Abidi and madhuri (2012). Esmaili (2008) has worked on a study of structural RC shear wall system of a 56-storey RC tall building. He has concluded that using shear walls for both gravity and bracing system is unacceptable neither conceptually nor economically also not only main walls are assumed to carry seismic loads, but also they are going to bear a significant percentage of gravity loads. Humar and Yavari (2002) have worked out design of concrete shear wall building for earthquake induced torsion.

\section{MODELING OF STRUCTURE}

In this present study, G+11 storey precast load bearing wall structure is taken for analysis. The modeling and analysis has been done in using ETABS. The parametric study has been done to observe the effect of out of plane moments, tensile force, shear force, storey drift, lateral load and storey shear on shear walls by using seismic zones II to $\mathrm{V}$ and Wind speeds from $33 \mathrm{~m} / \mathrm{sec}$ to $50 \mathrm{~m} / \mathrm{sec}$. Finally data base is prepared for various storey levels. The emphasis is on the analysis of load bearing wall structure under lateral loads. 
Table: 1 Material property for wall element

\begin{tabular}{|l|l|}
\hline Material name & Concrete \\
\hline Type of material & Isotropic \\
\hline Mass Per Unit Volume & $2.5 \mathrm{kN} / \mathrm{m}^{3}$ \\
\hline Modulus of elasticity & $32 \mathrm{kN} / \mathrm{mm}^{2}$ \\
\hline Poisson's ratio & 0.2 \\
\hline Concrete strength & $30 \mathrm{MPa}$ \\
\hline Section name & Wall \\
\hline Wall thickness & $150 \mathrm{~mm}$ \\
\hline
\end{tabular}

The lateral load analysis that is seismic and wind analysis requires certain parameters to be assigned in ETABS. These parameters are listed in table. 2

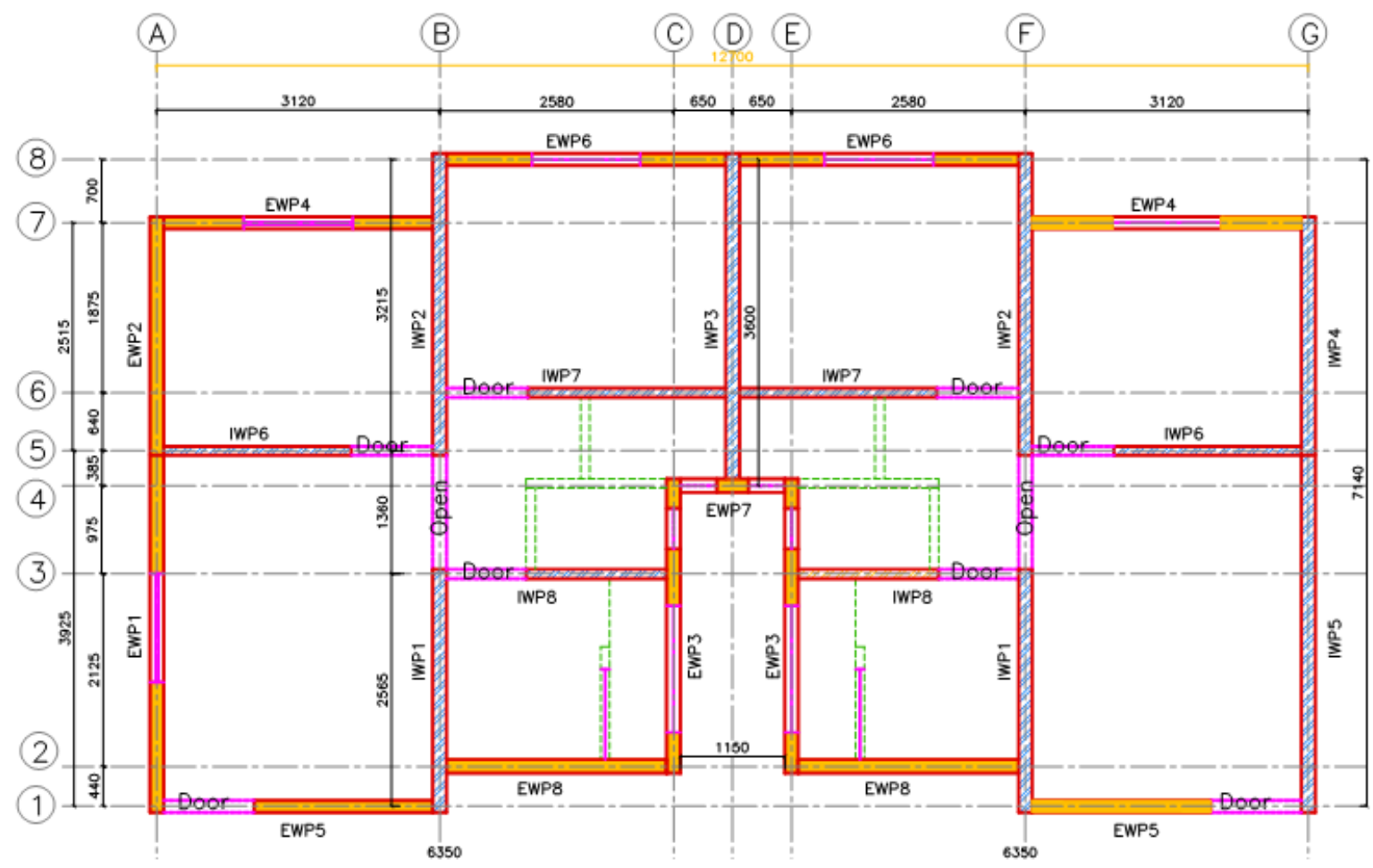

Fig.1 A typical two flats floor plan of structure

\section{DESIGN SPECTRUM CALCULATIONS}

The design horizontal seismic coefficient Ah for a structure shall be determined by the following expression:

$$
A_{h}=\frac{Z I S_{a}}{2 R g}
$$

Where

$\mathrm{Z}=$ Zone factor is for the Maximum Considered Earthquake (MCE) and service life of structure in a zone. The factor 2 in the denominator of $\mathrm{Z}$ is used so as to reduce the Maximum Considered Earthquake (MCE) zone factor to the factor for Design Basis Earthquake (DBE).

I= Importance factor, depending upon the functional use of the structures, characterized by. Hazardous consequences of its failure, post-earthquake functional needs, historical value.

$\mathrm{R}=$ Response reduction factor, depending on the perceived seismic damage performance of the structure, characterized by ductile or brittle deformations. However, the ratio (I/R) shall not be greater than 1.0.

$\mathrm{Sa} / \mathrm{g}=$ Average response acceleration coefficient.

\section{DESIGN WIND SPEED $\left(V_{z}\right)$}

The basic wind speed $\left(\mathrm{V}_{\mathrm{b}}\right)$ shall be modified to include the following effects to get design wind velocity at any height $\left(V_{z}\right)$ for the chosen structure

- Risk level

- Terrain roughness, height and size of structure and

- Local topography. 
It can be mathematically expressed as follows:

$$
V_{z}=V_{b} K_{1} K_{2} K_{3}
$$

Where

$\mathrm{V}_{\mathrm{Z}}=$ design wind speed at any height $\mathrm{z}$ in $\mathrm{m} / \mathrm{s}$;

$\mathrm{K}_{1}=$ probability factor (risk coefficient)

$\mathrm{K}_{2}=$ terrain, height and structure size factor and

$\mathrm{K}_{3}=$ topography factor

NOTE: Design wind speed up to IO m height from mean ground level shall be considered constant.

\section{DESIGN WIND PRESSURE}

The design wind pressure at any height above mean ground level shall be obtained by the following relationship between wind pressure and wind velocity.

$$
p_{z}=0.6 V_{z}^{2}
$$

Where

$\mathrm{P}_{\mathrm{z}}=$ Design wind pressure in $\mathrm{N} / \mathrm{m}^{2}$ at height $\mathrm{z}$, and

$\mathrm{V}_{\mathrm{z}}=$ design wind velocity in $\mathrm{m} / \mathrm{s}$ at height 2 .

NOTE - The coefficient 0'6 (in SI units) in the above formula depends on a number of factors and mainly on the atmospheric pressure and air temperature. The value chosen corresponds to the average appropriate Indian atmospheric conditions.

\subsection{Wind Load on Individual Members}

When calculating the wind load on individual structural elements such as roofs and walls, and individual cladding units and their fittings, it is essential to take account of the pressure difference between opposite faces of such elements or units. For clad structures, it is, therefore, necessary to know the internal pressure as well as the external pressure. Then the wind load, F, acting in a direction normal to the individual structural element or cladding unit is

$$
F=\left(C_{p e}-C_{p i}\right) A P_{\alpha}
$$

Where

$\mathrm{C}_{\mathrm{e}}=$ external pressure coefficient,

$\mathrm{C}_{\mathrm{i}}=$ internal pressure- coefficient,

$\mathrm{A}=$ surface area of structural or cladding unit, and

\begin{tabular}{|c|c|c|c|}
\hline \multicolumn{2}{|c|}{$\begin{array}{l}\text { Seismic coefficients } \\
\text { AS PER IS: } 1893-2000\end{array}$} & \multicolumn{2}{|c|}{$\begin{array}{l}\text { Wind Coefficients } \\
\text { AS PER IS: 875-1987 }\end{array}$} \\
\hline $\begin{array}{l}\text { Seismic Zone } \\
\text { Factor }\end{array}$ & 0.1 & Wind speed $\left(\mathrm{V}_{\mathrm{b}}\right)$ & $\begin{array}{l}33-50 \\
\mathrm{~m} / \mathrm{s}\end{array}$ \\
\hline Soil Type & III & Terrain Category & I \\
\hline $\begin{array}{l}\text { Importance } \\
\text { Factor }(\mathrm{I})\end{array}$ & 1 & Structure Class & B \\
\hline Response & 3 & Risk $\quad$ Coefficient & 1 \\
\hline
\end{tabular}

$\mathrm{P}_{\mathrm{d}}=$ design wind pressure element

\begin{tabular}{|c|c|c|}
\hline \multirow[t]{4}{*}{ Reduction (R) } & $\mathrm{k}_{1}$ factor & \\
\hline & $\begin{array}{ll}\text { Topography } & \mathrm{k}_{3} \\
\text { factor }\end{array}$ & 1 \\
\hline & $\begin{array}{l}\text { Windward } \\
\text { coefficient }\end{array}$ & 0.8 \\
\hline & $\begin{array}{l}\text { Leeward } \\
\text { coefficient }\end{array}$ & 0.5 \\
\hline
\end{tabular}

Table: 2 Seismic and wind parameters

\section{RESULTS AND DISCUSSIONS}

Shear wall structure having G+11 storey is analysed for garvity and latral loads for the different wind and seismic zones in India. The analysis is carried out using ETABS and data base is prepared for different storey levels as follows.

\subsection{Effect of Seismic Forces on Shear Wall}

\section{Structure}

In this present study, the data base is prepared for the seismic zone II to $\mathrm{V}$ of India. The effect of axial force, out of plane moments, lateral loads, shear force, storey drift, storey shear and tensile force are tabulated for different stories.

\subsubsection{Effect of Out-of-Plane Moments on Shear} Wall

Load bearing RCC walls are slender compression elements subjected to in and out-of-plane bending. For the worst load combination, out-of- plane moments in the wall is plotted on $y$-axis against at each storey level. It is concluded from Fig. 2 that the maximum out-of- plane moments in walls of storey one is $167107.18 \mathrm{kN}-\mathrm{m}$ for zone-II and for zone-V is $571286.96 \mathrm{kN}-\mathrm{M}$. The difference in maximum out of plane moment of zone- II and zone - V is $29.25 \%$. It indicates that the variation in maximum out of plane moment with zone is non-linear for worst load combination.

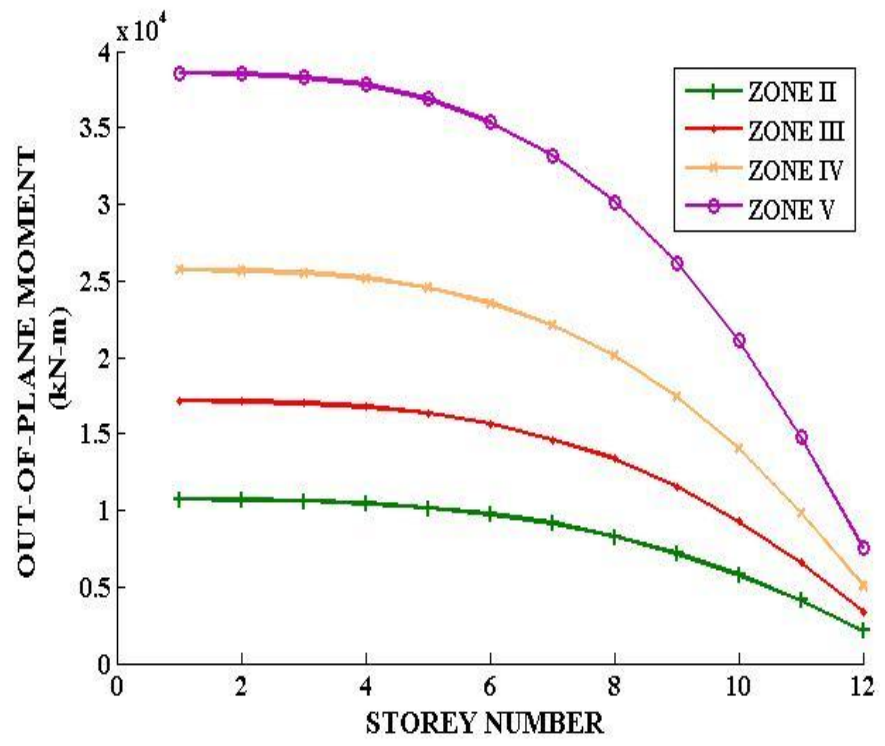

Fig: 2 Out-of-plane moment on shear wall due to seismic forces 


\subsubsection{Effect of Shear Force on Shear Walls}

Shearing forces are unaligned forces pushing one part of a body in one direction, and another part the body in the opposite direction. For the worst load combination shear force in the wall is plotted against at each storey level. From the Fig.3, it is observed that maximum lateral load in storey one for zone-II is $5519.86 \mathrm{kN}$ and for zone-V $19874.42 \mathrm{kN}$. The difference shear force between zone-II and zone-V is $27.77 \%$. It indicates that the variation in maximum shear force with storey level is non-linear for worst load combination.

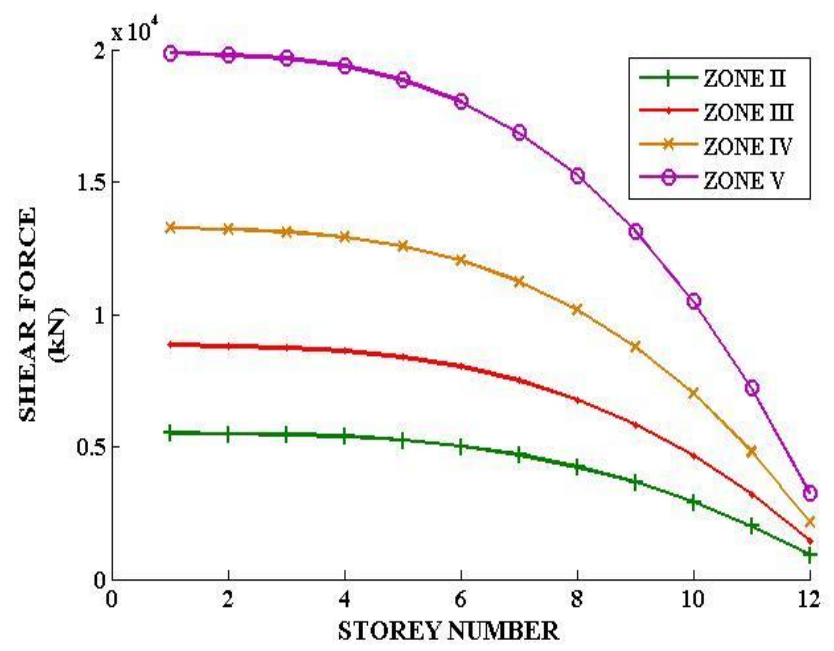

Fig: 3 Shear force on shear wall due to seismic forces

\subsubsection{Effect of Tensile Force on Shear Walls}

The tensile force is the maximum stress that a structure can withstand while being stretched or pulled before failing or breaking. Tensile strength is the opposite of compressive strength and the values can be quite different. For the worst load combination, tensile force in the wall is plotted against at each storey level. From the fig.4, it is observed that maximum tensile force in storey one in zone-II is $10711.9 \mathrm{kN}$ and for zone- $\mathrm{V}$ is $38572.83 \mathrm{kN}$. The difference in maximum tensile force between storey 11 and 12 is 51.92 $\%$ for zone $-\mathrm{II}$ and for zone-V is $51.47 \%$. It indicates that the variation in maximum tensile force with storey level is non-linear for worst load combination.

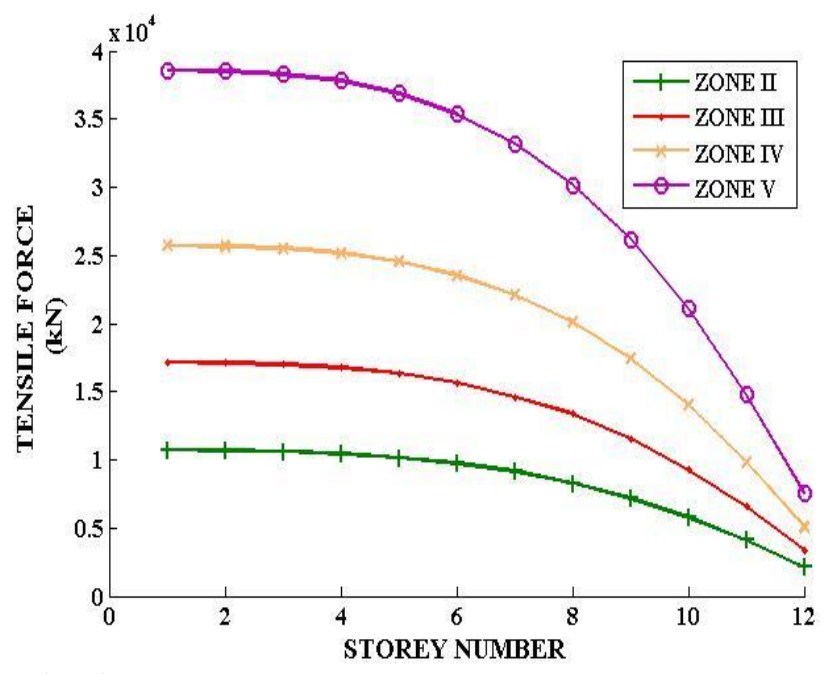

Fig: 4 Tensile force on shear wall due to seismic forces

\subsubsection{Effect of Maximum Storey Drift on Shear Walls}

One of the major shortcomings in high-rise structures is its increasing lateral displacements arising from lateral forces. For the worst load combination, storey drift in the wall is plotted on y-axis against at each storey level. From the fig.5, it is observed that maximum storey drift in storey 12 is $0.21 \mathrm{~mm}$ for zone-II and for zone- $\mathrm{V}$ is $0.735 \mathrm{~mm}$.

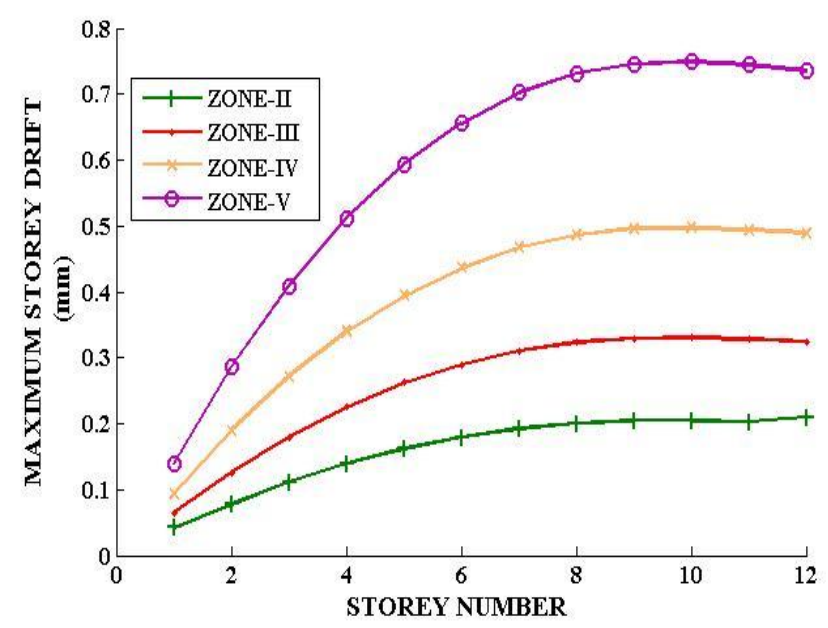

Fig: 5 Maximum storey drift on shear wall due to seismic forces

\subsubsection{Effect of Lateral Forces on Shear Walls}

The intensity of these loads depends upon the building's geographic location, height and shape. For the worst load combination lateral load in the wall is plotted against each storey level. From Fig.6, it is observed that maximum lateral load in storey 12 is $736.67 \mathrm{kN}$ and $3167.23 \mathrm{kN}$ for zone-II and for zone- $\mathrm{V}$ respectively. The difference in maximum lateral loads between storey 11 and 12 is $0.54 \%$ for zone-II and for zone- $\mathrm{V}$ is $3.84 \%$. It is observed form fig. 6 that this is non-linear variation of lateral load. 


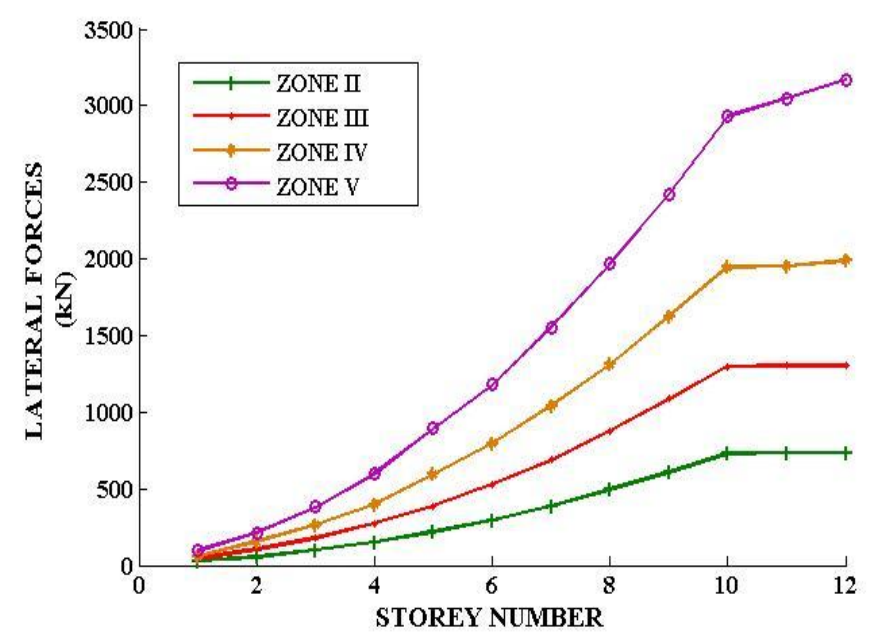

Fig: 6 Lateral forces on shear wall due to seismic forces

\subsubsection{Effect of Storey Shear on Shear Walls}

For the worst load combination, storey shear in the wall is plotted for each storey. From the Fig.7, it is observed that maximum storey shear in storey one is $907.77 \mathrm{kN}$ and $1958.46 \mathrm{kN}$ for zone- II and zone-V respectively. It indicates that the variation in maximum storey shear with storey level is non linear for worst load combination.

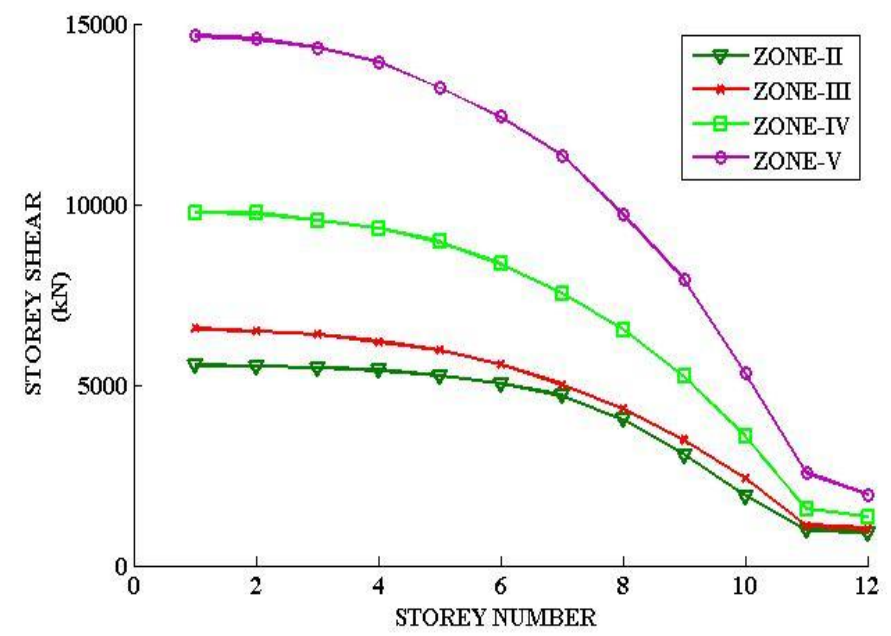

Fig: 7 Storey shear on shear wall due to seismic forces

\subsection{Effect of Wind Forces on Shear Wall Structure}

In this present study the data base is prepared for the wind zones in India for different major cities having basic wind speeds are $39 \mathrm{~m} / \mathrm{s}, 44 \mathrm{~m} / \mathrm{s}, 47 \mathrm{~m} / \mathrm{s}$ and $52 \mathrm{~m} / \mathrm{s}$ are consider for the study. The effect of axial force, out of plane moments, lateral loads, shear force, storey drift, storey shear and tensile force are observed for different stories.

\subsubsection{Effect of Out-of-Plane Moments on Shear Wall}

For the worst load combination, out-of- plane moments in the wall is plotted against each storey level. It is concluded from Fig.8 that the maximum out-of- plane moments in walls of storey one is for wind speed $39 \mathrm{~m} / \mathrm{s} 60965.48 \mathrm{kN}-\mathrm{m}$ and for the wind speed $50 \mathrm{~m} / \mathrm{s}$, it is $90357.6 \mathrm{kN}-\mathrm{m}$. The difference in maximum out of plane moment between wind speeds 39 to $50 \mathrm{~m} / \mathrm{sec}$ is $67.4 \%$.

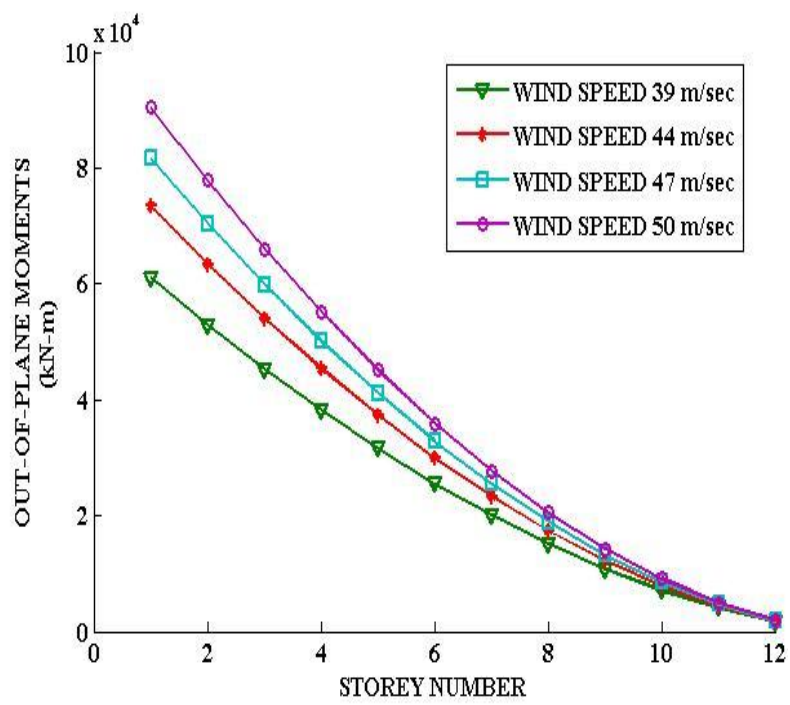

Fig: 8 Out-of-plane moments on shear walls due to wind forces

\subsubsection{Effect of Shear Force on Shear Walls:}

For the worst load combination shear force in the wall is plotted against at each storey level. From the Fig.9, it is observed that maximum lateral load in storey one for wind speed $39 \mathrm{~m} / \mathrm{s}$ is $2403.15 \mathrm{kN}$ and for wind speed $50 \mathrm{~m} / \mathrm{s}$ $3762.32 \mathrm{kN}$. The difference in maximum shear force between wind speed $39 \mathrm{~m} / \mathrm{s}$ and $50 \mathrm{~m} / \mathrm{s}$ is $36.126 \%$.

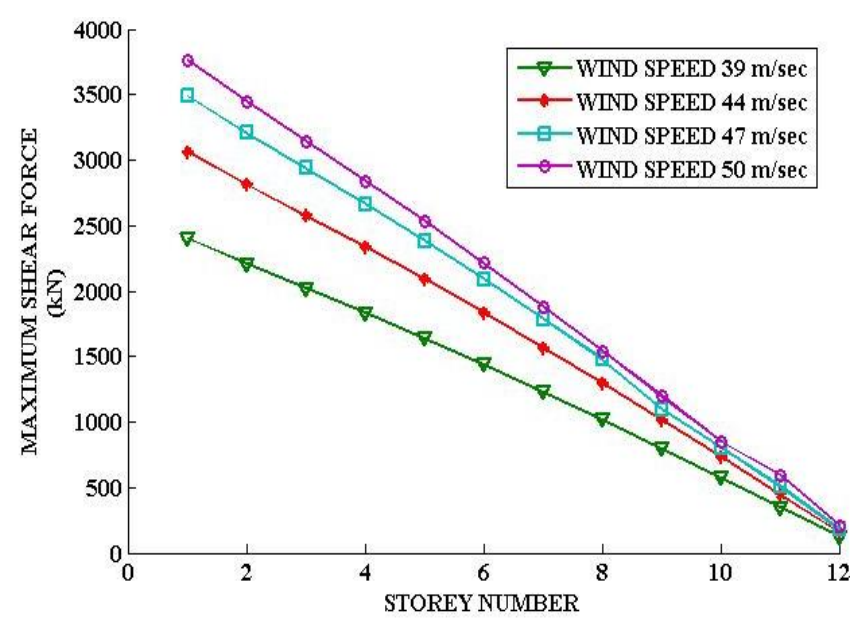

Fig: 9 Maximum shear forces on shear wall due to wind forces

\subsubsection{Effect of Tensile Force on Shear Walls}

For the worst load combination tensile force in the wall is plotted against at each storey level. From the Fig.10, it is observed that maximum tensile force in storey one with wind speed $39 \mathrm{~m} / \mathrm{s}$ is $307.22 \mathrm{kN}$ and for wind speed $50 \mathrm{~m} / \mathrm{s}$ is $540.976 \mathrm{kN}$. The difference in maximum tensile force 
between storey 11 and 12 is $13.17 \%$ and $19.84 \%$ for wind speed $39 \mathrm{~m} / \mathrm{s}$ and $50 \mathrm{~m} / \mathrm{s}$ respectively.

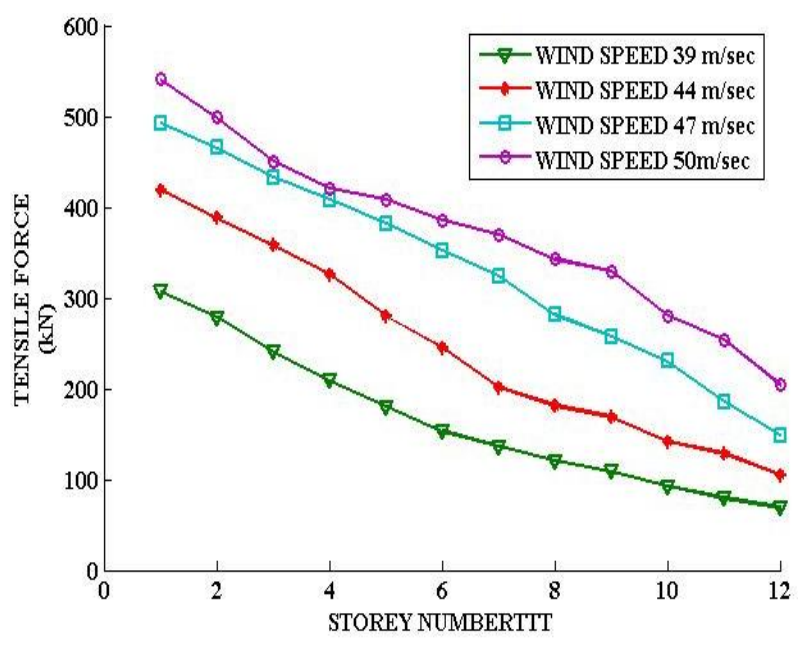

Fig: 10 Tensile forces on shear wall due to wind forces

\subsubsection{Effect of Maximum Storey Drift on Shear Walls}

For the worst load combination storey drift in the wall is plotted on y-axis against at each storey level. From the Fig.11, it is observed that maximum storey drift in between storey 12 is $0.0340 \mathrm{~mm}$ and $0.0591 \mathrm{~mm}$ for wind speed 39 $\mathrm{m} / \mathrm{s}$ and $50 \mathrm{~m} / \mathrm{s}$ resepctively. It indicates that the variation in maximum storey drift with storey level is non linear for worst load combination.

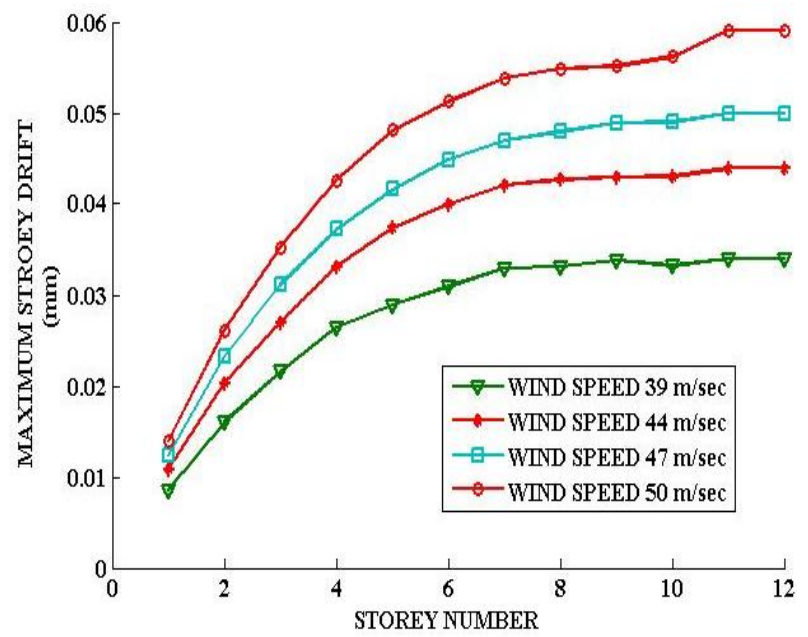

Fig: 11 Maximum storey drift on shear wall due to wind forces

\subsubsection{Effect of Lateral Forces on Shear Walls}

For the worst load combination lateral load in the wall is plotted against each storey level. From Fig.12, it is observed that maximum lateral load in storey 12 is $146.0 \mathrm{kN}$ and $240.3 \mathrm{kN}$ for wind speed $39 \mathrm{~m} / \mathrm{s}$ and $50 \mathrm{~m} / \mathrm{s}$ respectively.

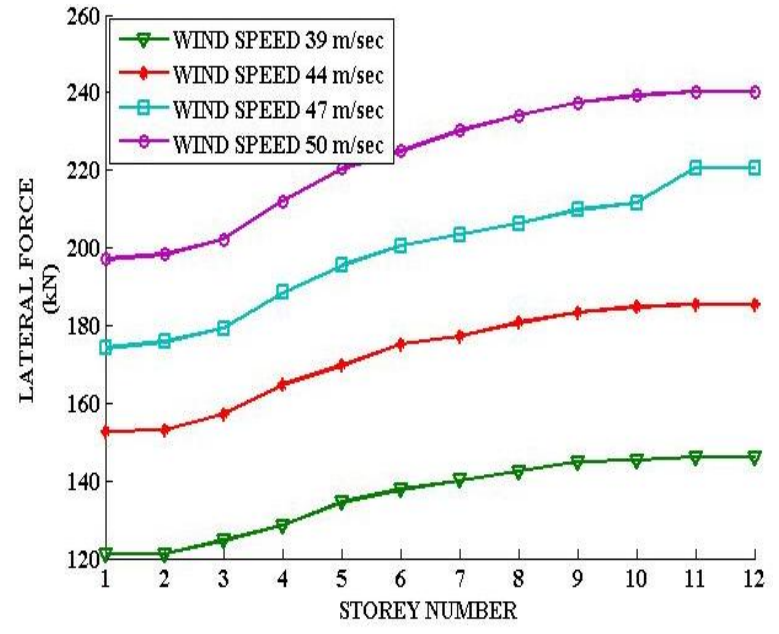

Fig: 12 Lateral forces on shear wall due to wind forces

\subsubsection{Effect of Storey Shear on Shear Walls}

For the worst load combination storey shear in the wall is plotted on y-axis against at each storey level. From the Fig.13, it is observed that maximum storey shear in storey one is $2403.15 \mathrm{kN}$ and $3762.32 \mathrm{kN}$ for wind speed $39 \mathrm{~m} / \mathrm{s}$ and $50 \mathrm{~m} / \mathrm{s}$ resepctively.

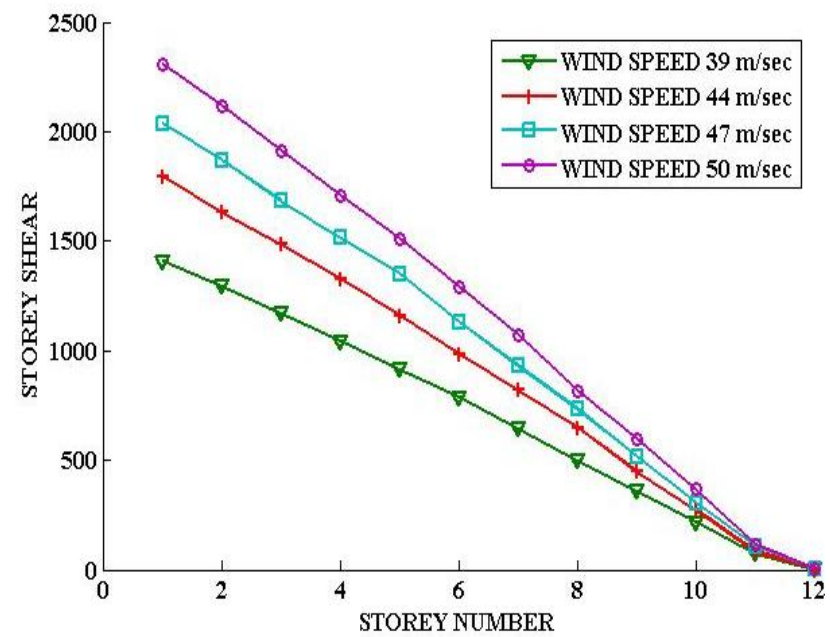

Fig: 13 Storey shear on shear wall due to wind forces

The data base is presented in table 3 which indicates the structural response in various seismic zones and wind speeds. The difference of structural response between each seismic zone is presented. Also the difference of structural response for consecutive basic wind speed is tabulated in table 3. 
Table 3 Structural response due to lateral loads for various zones

\begin{tabular}{|l|l|l|l|l|l|l|}
\hline Structure response & \multicolumn{2}{l|}{ SEISMIC EFFECT in (\%) } & \multicolumn{2}{l|}{ WIND EFFECT in (\%) } \\
\hline & \multicolumn{2}{l|}{ Response between zones } & \multicolumn{2}{l|}{ Response between wind speeds } \\
\hline & II -III & III-IV & IV-V & $\mathbf{3 9 - 4 4}$ & $\mathbf{4 4 - 4 7}$ & $\mathbf{4 7 - 5 0}$ \\
\hline Out-of-plane moment & 35.82 & 32.32 & 32.66 & 16.96 & 10.04 & 09.66 \\
\hline Shear force & 37.50 & 33.33 & 33.34 & 21.44 & 12.36 & 07.21 \\
\hline Tensile force & 37.49 & 33.33 & 33.37 & 26.68 & 14.93 & 08.93 \\
\hline Maximum storey drift & 33.38 & 33.54 & 33.47 & 22.51 & 12.20 & 15.39 \\
\hline Lateral loads & 43.53 & 34.43 & 37.18 & 21.21 & 15.98 & 08.20 \\
\hline Storey shear & 15.64 & 32.97 & 33.34 & 21.66 & 11.84 & 11.64 \\
\hline
\end{tabular}

\section{CONNECTION DETAILS}

The connection details in the precast construction plays vital role. This is an investigation of the seismic response on the precast structures due to the wall to wall and wall connection behavior. Earthquake could damage the whole structure if it is not properly designed, especially in high seismic regions. Connection is one of the crucial elements to limit building damage. A lot of researches have been done on monolithic reinforced concrete buildings but none of them gives information on the behavior of precast connection under seismic effect for the whole structure.

\subsection{Wall Connections}

As per is: $11447-1985$ code of practice for construction with large panel prefabrication

Vertical joints: Shear resistance of vertical joints shall be checked by the following formulae:

Keyed joint: Shear strength of reinforced keyed joint

$$
\mathrm{R}_{\mathrm{j}}=0.12 \frac{\sigma_{\mathrm{kc}}}{\gamma_{\mathrm{w}}}\left(\mathrm{A}_{\mathrm{k}}+\mathrm{A}_{\mathrm{ct}}\right)+2000 \Delta \mathrm{A}_{\mathrm{s}}
$$

$\mathrm{R}_{\mathrm{j}}=$ Ultimate shear capacity of the joint

$\sigma_{\mathrm{kc}}=$ Characteristic strength of concrete

$\gamma_{\mathrm{m}}=$ Strength reduction factor

$\mathrm{A}_{\mathrm{k}}=$ area of the key under consideration

$\mathrm{A}_{\mathrm{s}}=$ area of the transverse reinforcement in the key

$\mathrm{A}_{\mathrm{ct}}=$ total area of cross-section of shear-keys in the joint and area of cross-section of tie- beam respectively.

PVL140 is chosen from the peikko group technical manual for PVL Connecting loop. The minimum dimensions are as follows:

As per the peikko group technical manual for PVL connecting loop,

For PVL140: $\quad \mathrm{d}_{\text {joint }}=160 \mathrm{~mm}$, Overlap $=120 \mathrm{~mm} \mathrm{~d}_{\text {wall }}=$ $150 \mathrm{~mm}$

Depends on eccentricity for external wall $\mathrm{e}=0.2 \mathrm{t}_{\mathrm{w}}$ subjected to a maximum of $30 \mathrm{~mm}=0.2$
From peikko manual $9 \mathrm{~mm}$ diameter wire is chosen

$$
\begin{gathered}
\mathrm{R}_{\mathrm{j}}=0.12 \frac{\sigma_{\mathrm{kc}}}{\gamma_{\mathrm{w}}}\left(\mathrm{A}_{\mathrm{k}}+\mathrm{A}_{\mathrm{ct}}\right)+2000 \Delta \mathrm{A}_{\mathrm{s}} \\
\mathrm{R}_{\mathrm{j}}=209.8 \mathrm{kN} \text { (for one loop) }
\end{gathered}
$$

As per peikko group manual Picture 2, 4 no's of loops are provided for each wall

$\mathrm{R}_{\mathrm{j}}=$ Ultimate shear capacity of the joint $=209.8 \times 4=839 \mathrm{kN}<740 \mathrm{kN}$ Hence safe.

\subsection{Horizontal Wall Connection}

In case of joints without keys the shear resistance of horizontal joints shall be checked by the following formula if entire wall is in compression.

$$
R_{j}=2.0 A_{w}
$$

If high resistance is needed, the horizontal joint is to be provided with keys. The shear resistance of keyed joint shall be checked by the following formula:

When compressive forces are produced in the keys due to action of lateral forces

$$
\begin{gathered}
\mathrm{R}_{\mathrm{h} 1}=\mathrm{R}_{\mathrm{c} 1}+2.5 \frac{\mathrm{N}_{\mathrm{c}}}{\sqrt{\sigma_{\mathrm{kc}} / \gamma_{\mathrm{m}}}} \leq 1.4 \mathrm{R}_{\mathrm{c} 1} \\
\mathrm{R}_{\mathrm{c} 1}=0.12 \frac{\sigma_{\mathrm{kc}}}{\gamma_{\mathrm{w}}} \mathrm{A}_{\mathrm{k}}{ }^{\prime}+2000 \mathrm{~A}_{\mathrm{s}}{ }^{\prime}
\end{gathered}
$$

$\mathrm{A}_{\mathrm{k}}{ }^{\prime}=$ area of the key under consideration

$\mathrm{A}_{\mathrm{s}}=$ area of the transverse reinforcement in the key

When tensile forces are produced in the keys due to action of lateral forces

$$
\mathrm{R}_{\mathrm{h} 1}+\mathrm{R}_{\mathrm{t} 1}+1-\left(\frac{\mathrm{N}_{\mathrm{t}}}{\mathrm{A}_{\mathrm{s}} \sigma_{\mathrm{ks}} / \gamma_{\mathrm{w}}}\right)
$$


In which $\mathrm{R}_{\mathrm{t} 1}=0.06 \frac{\sigma_{\mathrm{kc}}}{\gamma_{\mathrm{w}}} \frac{\left(\sigma_{\mathrm{ks}}\right)^{\mathrm{n}_{\mathrm{d}}}}{\gamma_{\mathrm{w}}}$

Where

$\mathrm{R}_{\mathrm{h} 1}=$ strength of an individual key in horizontal joint

$\mathrm{R}_{\mathrm{cl}}=$ strength of the key when acted upon by shear forces parallel to the length of

Joint as given by following formulae

$80 \mathrm{~mm}$ diameter hole is considered for the shear key and $30 \mathrm{~mm}$ diameter rod for the transverse reinforcement in the key.

When compressive forces are produced in the keys due to action of lateral forces

$$
\begin{gathered}
\mathrm{R}_{\mathrm{c} 1}=0.12 \frac{\sigma_{\mathrm{kc}}}{\gamma_{\mathrm{w}}} \mathrm{A}_{\mathrm{k}}{ }^{\prime}+2000 \mathrm{~A}_{\mathrm{s}}{ }^{\prime} \\
\mathrm{R}_{\mathrm{c} 1}=72.48 \mathrm{kN} \\
\mathrm{R}_{\mathrm{h} 1}=\mathrm{R}_{\mathrm{c} 1}+2.5 \frac{\mathrm{N}_{\mathrm{c}}}{\sqrt{\sigma_{\mathrm{kc}} / \gamma_{\mathrm{m}}}} \leq 1.4 \mathrm{R}_{\mathrm{c} 1} \\
\mathrm{R}_{\mathrm{h} 1}=81 \mathrm{kN}<1.4 \mathrm{R}_{\mathrm{c} 1}, \text { Hence ok }
\end{gathered}
$$

Strength of individual key $=81 \mathrm{kN}$

- From the typical floor plan the typical wall length $3.120 \mathrm{~m}$ is considered.

- From the ETABS analysis the maximum lateral load is $740 \mathrm{kN}$

- For satisfying that lateral load 10 shear keys of 80 $\mathrm{mm}$ are required.

- The transverse reinforcement of $25 \mathrm{~mm}$ diameter rod required.

\section{CONCLUSIONS}

In this present work ETABS is used to analyze the shear wall structure of G+11precast load bearing wall structure considering the gravity and lateral loads. The following conclusions are drawn from present work.

- The variation of out-of-plane moments with storey level is non-linear. The difference in maximum out of plane moment between Zone- II and Zone-V is $29.25 \%$ and the difference in maximum out of plane moment between wind speeds 39 and $50 \mathrm{~m} / \mathrm{s}$ is $67.4 \%$.

- The variation of shear force with storey level is nonlinear. The difference shear force between zone-II and zone- $\mathrm{V}$ is $27.77 \%$ and for wind speed of $39 \mathrm{~m} / \mathrm{s}$ and $50 \mathrm{~m} / \mathrm{s}$ the difference in shear force is $36.126 \%$.

- The variation of tensile force with storey level is non linear. The difference in maximum tensile force between storey 11 and 12 is $51.92 \%$ for zone $-\mathrm{II}$ and that of for zone- $\mathrm{V}$ is $51.47 \%$. The difference in maximum tensile force for wind speed of $39 \mathrm{~m} / \mathrm{s}$ and $50 \mathrm{~m} / \mathrm{s}$ is $13.17 \%$ and $19.84 \%$ respectively.
- The maximum storey drift is increasing while increasing the storey level. It is observed that maximum storey drift in between storey 11 and 12 is $0.21 \mathrm{~mm}$ for zone-II and for zone-V is $0.735 \mathrm{~mm}$. The maximum storey drift for wind speed of $39 \mathrm{~m} / \mathrm{s}$ and $50 \mathrm{~m} / \mathrm{s}$ is $0.0340 \mathrm{~mm}$ and $0.0591 \mathrm{~mm}$ respectively.

- The difference in maximum lateral loads between storey 11 and 12 is $0.54 \%$ for zone-II and $3.84 \%$, for zone-V. Maximum lateral load for wind speed $39 \mathrm{~m} / \mathrm{s}$ and $50 \mathrm{~m} / \mathrm{s} 146.00 \mathrm{kN}$ and $240.30 \mathrm{kN}$ respectively. The variation of lateral force with storey level is non-linear.

- The variation in maximum storey shear with storey level is non linear for worst load combination. The maximum storey shear in storey one is $907.77 \mathrm{kN}$ for zone- II and for zone $-\mathrm{V}$ is $1958.46 \mathrm{kN}$, and for wind speed $39 \mathrm{~m} / \mathrm{s}$ and $50 \mathrm{~m} / \mathrm{s}$ the maximum storey shear is $2403.15 \mathrm{kN}$ and $3762.32 \mathrm{kN}$ respectively.

\section{REFERENCES}

[1] Devi G.N, Subramanian.K and Santhakumar A.R (2009) "Structural response of multibay multistory lateral load resisting systems under seismic type loading" International journal of earth science and engineering vol. 02, June 2009, PP. 145-153.

[2] Venkatesh S.V and Bai S.V (2011) " Effect of internal and external shear wall on performance of building frame subjected to lateral load " International journal of earth sciences and engineering vol. 04, no 06 SPL October 2011, PP. 571-576.

[3] Balkaya C and Kalkan E S.M (2004) “"ThreeDimensional effect on openings of laterally loaded pierced shear walls" Journal of structural engineering October 2004, PP. 1506-1514.

[4] Janaraj T, Dhanasekar M and Haider W (2011) "Wider reinforced masonry shear walls subjected to cyclic lateral loading" Architecture civil engineering environment No.4 PP.39-46.

[5] Kevadkar M.D and Kodag P.B (2013) "Lateral load analysis of R.C.C Building” International journal of modern Engineering research Vol.3. Issue.3 mayjune 2013 PP- 1428-1434.

[6] Carpinteri A, Corrado, Lacidogna G and Cammarano S (2012) "Lateral load effect on tall shear wall structures of different height" Structural engineering and Mechanics, vol. , No.3 PP.313-337.

[7] Agrawal A and Charkha S.D (2012) "Effect of change in shear wall location on storey drift on multistory building subjected to lateral loads" International journal of engineering research and applications" Vol. 2 Issue 3 May-June 2012, PP. 1786-1793.

[8] Rahman A, Fancy F.S and Bobby A.S (2012) “ Analysis of drift due to wind loads and earthquake loads on tall structures by programming language $\mathrm{C}$ “ International journal of scientific \& Engineering research, Vol.3 Issue 6, June-201. 
[9] Arum C and Akinkunmi A (2011) "Comparison of wind-induced displacement characteristics of buildings with different lateral load resisting system" Scientific Research Vol.3 PP. 236-247.

[10] Abidi M andMadhuri M.N (2012) "review on shear wall for soft storey high-rise buildings" International journal of engineering and advanced technology Vol.1 Issue-6 PP.52-54.

[11] Esmaili O, Epackachi S, Samadzad M and mirghaderi S.R (2008) "study of structural RC shear wall system in a 56-storey RC tall building" The $14^{\text {th }}$ world conference on earthquake engineering October 12-17Beijing,China.

[12] Humar J.L and Yavari S (2002) "Design of concrete shear wall buildings for earthquake induced torsion" $4^{\text {th }}$ Structural specialty conference of the Canadian society for civil engineering june 5-8. 